\title{
MAHKAMAH SYARIAH DI MALAYSIA: KEMAJUAN DAN PENCAPAIAN ${ }^{1}$
}

\author{
Mohamed Azam Mohamed Adil*
}

\begin{abstract}
Malaysia's Shariah court system long predates the country's Independence in 1957 and has since undergone a series of developments. Yet the Shariah court's jurisdiction remains limited by the Parliament and the Federal Constitution. This limited jurisdiction has triggered an on-going conflict between Shariah courts and civil courts. This article discusses the jurisdiction of Shariah court prior to and after the landmark amendment inserting Article 121 (1A) into the Malaysian Federal Constitution. It also discusses the challenges faced by the Shariah courts within and outside the system. This article suggests that the present jurisdiction of the Shariah courts should be reviewed, and that the civil courts should not interfere with the jurisdiction that has been awarded to the Shariah courts, even if that jurisdiction is only implied. This article ends with a suggestion that a Special court should be set up to adjudicate cases pertaining to Islamic law but involving parties of different faiths.

Keywords: Shariah Court; Civil Court; conflict of jurisdictions; developments; achievements.
\end{abstract}

\section{Pendahuluan}

Mahkamah Syariah di Malaysia telah melalui beberapa perubahan semenjak pindaan Perkara 121 (1A) pada tahun 1988 dan penubuhan Jabatan Kehakiman Syariah Malaysia (JKSM) pada tahun 1998. Walaupun begitu, bidang kuasa jenayah Mahkamah Syariah masih tidak berubah semenjak pindaan terhadap Akta Mahkamah Syariah (Bidang Kuasa Jenayah) 1965 (pindaan 1984) yang memberi bidang kuasa kepada Mahkamah Syariah menjatuhkan hukuman tiga tahun penjara, denda RM5,000.00 dan sebatan enam kali. Terdapat cadangan untuk meminda bidang kuasa ini oleh Menteri di Jabatan Perdana Menteri tetapi ia masih belum menjadi kenyataan sehingga artikel ini ditulis. ${ }^{2}$

Satu kajian menyeluruh telah dibuat oleh Institut Kefahaman Islam Malaysia (IKIM) dengan kerjasama Jabatan Perdana Menteri (JPM), JKSM, Jabantan Kemajuan Islam Malaysia (JAKIM), Universiti Islam Antarabangsa Malaysia 
(IIUM), Jabatan Peguam Negara, dan beberapa agensi kerajaan lain. "Kajian Pemacuan Transformasi Sistem Perundangan Islam di Malaysia" (2010-2012) tersebut menyentuh kesemua aspek yang melibatkan perundangan Islam di Malaysia termasuk pelan tindakan transformasi Mahkamah Syariah.

Artikel ini menganalisa dan menilai kemajuan dan pencapaian Mahkamah Syariah sejak pindaan Perkara 121 (1A) Perlembagaan Persekutuan dan penubuhan JKSM pada tahun 1998. Kertas ini juga mencadangkan beberapa tindakan yang perlu diambil bagi melihat transformasi yang sedang diusahakan mencapai kejayaan.

\section{Sejarah Undang-undang Islam di Malaysia}

Kedatangan Islam ke Nusantara pada abad ke-13 dan Melaka pada abad ke-14 telah mengubah landskap perundangan yang banyak terpengaruh dengan adat. Hatta semasa kegemilangan kesultanan Melaka, undang-undang Islam bercampur adat Temenggong lalu membentuk apa yang dikenali sebagai Kanun Melaka. ${ }^{3}$

Undang-undang Melaka banyak merujuk kepada teks Abu Shuja' dan Fath al-Qarib yang ditulis oleh Ibn al-Qasim al-Ghazzi. Beberapa undang-undang Melaka yang termasyhur terdiri daripada Undang-Undang Melaka Asal, UndangUndang Laut, Undang-Undang Keluarga Islam dan Undang-Undang Jualbeli dan Acara Islam. Undang-Undang Melaka juga telah mempengaruhi undang-undang negeri lain seperti Undang-Undang 99 Perak, Undang-Undang Johor, UndangUndang Pahang dan lain-lain. ${ }^{4}$

Undang-undang Islam telah menjadi undang-undang utama di Tanah Melayu. Ini telah dibuktikan dalam Shaikh Abdul Latif \& Others lwn Shaikh Elias Bux ${ }^{5}$ di mana mahkamah memutuskan bahawa undang-undang Islam yang diubahsuai dengan adat tempatan terpakai ke atas orang Islam. Pandangan yang sama juga diputuskan dalam kes Ramah lwn Laton ${ }^{6}$ di mana mahkamah semasa penjajahan Inggeris mengiktiraf undang-undang Islam sebagai undang-undang tempatan Tanah Melayu.

Namun begitu, hakikatnya undang-undang Islam tidak diberi tempat yang sewajarnya semasa penjajahan Inggeris. Undang-undang Inggeris secara perlahan-lahan telah diperkenalkan oleh Inggeris. Ini dapat dilihat dalam Kanun Jenayah, Enakmen Keterangan, Enakmen Kontrak, Kanun Acara Sivil, Kanun Acara Jenayah dan Kanun Tanah. ${ }^{7}$

Begitu juga, undang-undang Inggeris diterima pakai melalui keputusankeputusan mahkamah. Ini kerana, dalam amalan common law, keputusan mahkamah yang lebih tinggi mengikat mahkamah bawahan dan keputusan sebelum mengikat keputusan mahkamah yang mendatang. Tambahan pula, hakim yang mendengar kes-kes adalah orang Inggeris, maka mereka sudah tentu 
terpengaruh dengan undang-undang Inggeris. Ia juga menjadi rujukan mahkamah sekiranya tidak terdapat undang-undang bertulis. Ini dapat dilihat dalam beberapa kes seperti Myriam lwn Ariff ${ }^{8}$ yang mengenepikan keputusan Mahkamah Syariah yang mengikut hukum Syarak yang memberi hak penjagaan anak kepada bapa. Mahkamah Tinggi memberi alasan ia mempunyai bidang kuasa dan apabila pertindihan bidang kuasa berlaku antara Mahkamah Syariah dan Mahkamah Tinggi Sivil, maka Mahkamah Sivil mempunyai bidang kuasa. Keputusan dalam kes Ainan lwn Syed Abu Bakar ${ }^{9}$ juga dengan jelas mengenepikan undang-undang Islam mengenai persoalan anak sah taraf dengan merujuk kepada seksyen 121 Akta Keterangan.

\section{Sejarah Penubuhan Mahkamah Syariah}

Dari segi sejarah, Mahkamah Syariah di Malaysia wujud semenjak sebelum merdeka. Ia terdiri daripada Mahkamah Kadi Besar dan Mahkamah Kadi. Keskes rayuan didengar di Mahkamah Jawatankuasa Ulang Bicara. Kadi-kadi dilantik oleh Sultan/Raja masing-masing. Kedudukan ini berkekalan sehingga pada tahun 1980an Mahkamah Syariah telah dipisahkan dari Jabatan Agama Islam. Pada tahun 1990an, kedudukan Mahkamh Syariah telah dipertingkat dengan penstrukturan semula hierarki mahkamah dan penamaan semula nama mahkamah. Mahkamah Syariah terdiri dari Mahkamah Rendah Syariah, Mahkamah Tinggi Syariah dan Mahkamah Rayuan Syariah. ${ }^{10}$

Sebagai contohnya, Akta Pentadbiran Undang-Undang Islam (Wilayah Persekutuan) 1993 memperkenalkan struktur baru yang berkonsepkan three-tier hierarchy di mana ketiga-tiga hierarki Mahkamah Syariah mempunyai bidang kuasa masing-masing yang meliputi:

i. Mahkamah Rendah Syariah yang mempunyai bidang kuasa sivil dan jenayah;

ii. Mahkamah Tinggi Syariah yang mempunyai bidang kuasa asal dan juga rayuan; dan

iii. Mahkamah Rayuan Syariah yang merupakan Mahkamah Tertinggi. ${ }^{11}$

Dengan perubahan hierarki dan struktur Mahkamah Syariah, nama jawatan juga ditukar. Mahkamah Syariah diketuai oleh Ketua Hakim Syar'ie yang dibantu oleh hakim-hakim mahkamah Tinggi dan Rendah. Perlantikan hakim-hakim Syar'ie dilantik oleh Sultan/Raja. Perlantikan hakim Mahkamah Rendah dibuat melalui proses biasa di bawah skim perkhidmatan awam atas cadangan Ketua Hakim Syar'ie. Hakim-hakim Mahkamah Tinggi juga dilantik oleh Sultan/Raja atas perakuan Ketua Hakim Syar'ie. Hakim-hakim Mahkamah Rayuan Syariah 
pula terdiri daripada seorang pengerusi dan beberapa hakim yang dilantik dari kalangan Hakim Rayuan JKSM dan yang bukan berjawatan hakiki untuk menganggotai panel rayuan. ${ }^{12}$

Penubuhan JKSM pada tahun 1998 bertujuan antara lain mempersekutuankan perkhidmatan Mahkamah Syariah seluruh negara dengan mengambilkira struktur organisasi, kuasa dan pencapaian. Ia meliputi bidang tugas pegawai Syariah, beban tugas dan tanggungan Kerajaan Persekutuan dan Negeri serta kemudahan yang dinikmati oleh Pegawai Syariah.

Perkara lain yang menyebabkan tertubuhnya JKSM ialah kerana kewujudan masalah ketidakseragaman keputusan Mahkamah Syariah kerana terdapat perbezaan peruntukan dalam Enakmen Pentadbiran Agama Islam dan tatacara pelantikan hakim-hakim Mahkamah Rendah Syariah, Mahkamah Tinggi Syariah dan Mahkamah Rayuan Syariah serta kekurangan hakim di Mahkamah Syariah seluruh negara yang menyebabkan banyak kes tertunggak. ${ }^{13}$

\section{Bidang Kuasa Mahkamah Syariah - Terhad, Tersurat dan Tersirat ${ }^{14}$}

Salah satu persoalan besar dalam Mahkamah Syariah ialah bidang kuasa yang terhad yang diberi oleh Parlimen dan Perlembagaan Persekutuan. Ini kerana Jadual Kesembilan, Senarai II Senarai Negeri Perlembagaan Persekutuan menghadkan bidang kuasa Mahkamah Syariah ke atas mereka yang menganut agama Islam dan setakat mana yang diberi oleh undang-undang Persekutuan yang meliputi undang-undang diri dan keluarga, termasuk megenai perwarisan, wakaf, zakat, Baitulmal, masjid dan tempat sembahyang bagi orang Islam, dan pengwujudan dan penghukuman kesalahan yang dilakukan oleh orang Islam terhadap perintah agama tersebut. Dari segi hukuman pula, Akta Mahkamah Syariah (Bidang kuasa Jenayah) 1965 (Pindaan 1984) memperuntukkan bidang kuasa jenayah Mahkamah Syariah hanya terhad kepada tiga tahun penjara; denda RM5,000.00 dan enam kali sebatan. Bidang kuasa ini lebih rendah dari Mahkamah Sesyen dan Mahkamah Majistret yang disifatkan dalam Perlembagaan sebagai "mahkamah bawahan" (inferior courts).

Malah sebelum tahun 1988, terdapat kes-kes yang berkaitan dengan undangundang Islam yang diadili di Mahkamah Sivil. Ini menimbulkan masalah kerana hakim Mahkamah Sivil tidak mempunyai latar belakang Syariah dan undangundang Islam.

Satu pindaan Perlembagaan telah dibuat pada tahun 1988 di mana Perkara 121 telah dipinda dengan memasukkan (1A). Tujuan sebenar Parlimen berbuat demikian adalah untuk memastikan tiada campur tangan Mahkamah Sivil ke atas kes-kes yang bidang kuasanya dianugerahkan ke atas Mahkamah Syariah 
seperti yang diperuntukkan dalam Jadual Kesembilan Senarai II Senarai Negeri, Perlembagaan Persekutuan. ${ }^{15}$ Namun, realitinya Mahkamah Sivil masih "bertegas" untuk mendengar kes-kes yang melibatkan undang-undang Islam. Sehinggalah pada tahun 1992 dalam kes Mohamed Habibullah bin Mahmood lwn Faridah bt. Dato' Talib $^{16}$, di mana Mahkamah Persekutuan memutuskan bahawa Mahkamah Sivil tidak mempunyai bidang kuasa yang diperuntukkan kepada Mahkamah Syariah. Ini diikuti oleh kes Soon Singh a/l Bikar Singh lwn PERKIM, $K e{ }^{17}{ }^{17}$ di mana Mahkamah Persekutuan memutuskan bahawa Mahkamah Syariah mempunyai bidang kuasa membuat keputusan keluar dari agama Islam walaupun tiada peruntukan tersurat mengenai perkara itu. Memadailah dengan menganggap bidang kuasa terhadap kes murtad dimiliki oleh Mahkamah Syariah secara tersirat, berdasarkan peruntukan perlembagaan.

Namun, pertelingkahan dan pertindihan bidang kuasa antara Mahkamah Sivil dan Mahkamah Syariah tidak berhenti. Beberapa kes jelas menunjukkan bahawa ada kecenderungan hakim Mahkamah Sivil yang masih tidak dapat menerima hakikat pindaan Perkara 121 (1A) yang mengeluarkan bidang kuasa Mahkamah Sivil dari mendengar kes yang berkaitan dengan undang-undang Islam. Persoalan timbul sama ada sesuatu peruntukan bidang kuasa itu diberikankepada Mahkamah Syariah adalah secara tersurat atau tersirat. Apa yang menimbulkan khilaf ialah sama ada bidang kuasa mahkamah Syariah perlu diberi oleh enakmen negeri secara langsung dan tersurat, contohnya melalui Enakmen Pentadbiran UndangUndang Islam, atau bolehkan bidang kuasa dianggap tersirat bagi mahkamah Syariah semata-mata kerana perlembagaan memberikan peruntukan bidangbidang tertentu bagi kerajaan negeri meskipun enakmen negeri tidak memberi peruntukan.

\section{Pendekatan pertama: bidang kuasa perlu dikurniakan secara tersurat}

Menurut pendekatan ini, Mahkamah Syariah hanya memiliki bidang kuasa jika bidang kuasa tersebut dikurniakan secara tersurat oleh Enakmen Negeri, meskipun perlembagaan (Jadual Kesembilan, Senarai II-Senarai Negeri) jelas menyenaraikan bidang-bidang tertentu seperti perundangan Islam, sebagai tertakluk di bawah kuasa kerajaan negeri. Ini kerana senarai tersebut hanyalah sekadar senarai yang memberi kuasan dan keizinan kepada kerajaan negeri untuk menggubal undang-undang antara lain bagi mengurniakan bidang kuasa kepada Mahkamah Syariah secara tersurat. Jika kerajaan negeri gagal mengurniakan bidang kuasa melalui undang-undang yang berkenaan, maka Mahkamah Syariah dianggap tidak memilik bidang kuasa.

Pendekatan ini dapat dilihat dalam kes $\mathrm{Ng}$ Wan Chan lwn Majlis Agama Islam Wilayah Persekutuan dan satu lagi ${ }^{18}$ di mana pertikaian timbul antara balu si mati dan Majlis Agama Islam sama ada si mati semasa meninggal dunia 
adalah seorang Buddha atau Islam. Si balu memohon supaya Mahkamah Tinggi mengeluarkan injunksi interlocutory supaya mayat suaminya tidak diserah kepada Majlis. Majlis kemudiannya mempertikaikan bidang kuasa Mahkamah Tinggi kerana pada pandangan Majlis, kes ini terletak di bawah bidang kuasa Mahkamah Syariah Kuala Lumpur. Mahkamah Tinggi berpendapat seksyen 45(2) dan (3) Enakmen Pentadbiran Hukum Syarak 1952 Negeri Selangor yang terpakai ke atas Wilayah Persekutuan tidak memperuntukkan bidang kuasa kepada Mahkamah Syariah dalam memutuskan seseorang itu seorang Islam atau tidak semasa kematiannya. Hakim Eusoff Chin berkata:

"Sekiranya undang-undang negeri tidak menganugerahkan kepada Mahkamah Syariah sebarang bidang kuasa untuk menangani sesuatu perkara seperti yang tersenarai di bawah Senarai Negeri, Mahkamah Syariah terkeluar dari mengendalikan perkara tersebut. Bidang kuasa tidak dimiliki secara tersirat". ${ }^{19}$

Justeru itu, Mahkamah Tinggi Sivil mempunyai bidang kuasa untuk membuat keputusan. Mahkamah Tinggi memutuskan bahawa keterangan yang diberi membuktikan bahawa perbuatan si mati semasa hayatnya tidak mengikut ajaran Islam, maka si mati bukanlah seorang Islam semasa kematiannya.

Pendekatan yang sama juga diambil dalam kes Lim Chan Seng lwn Pengarah Jabatan Agama Islam, Pulau Pinang \& Satu Lagi ${ }^{20}$ di mana dalam kes ini Mahkamah Tinggi Pualau Pinang menerima pandangan bahawa persoalan mengenai penentuan akidah seseorang Islam adalah terletak di bawah Bahagian 1 Senarai Negeri, Jadual Kesembilan, Perlembagaan Persekutuan. Walau bagaimanapun, Hakim Dato' Abdul Hamid Mohamad (ketika itu) memutuskan bahawa Mahkamah Sivil merupakan mahkamah yang kompeten untuk mendengar kes permohonan murtad memandangkan bahawa tidak terdapat peruntukan yang nyata dalam Enakmen Negeri Pulau Pinang yang memberi kuasa kepada Mahkamah Syariah untuk berbuat demikian. ${ }^{21}$

Ini juga dapat dilihat dalam kes Shaik Zolkaffly Shaik Natar \& Lain-lain lwn Majlis Agama Islam Pulau Pinang, ${ }^{22}$ pandangan yang sama juga diambil oleh hakim yakni apabila terdapatnya pertikaian bidang kuasa Mahkamah Tinggi, persoalan pokok bukan sama ada Mahkamah Tinggi mempunyai bidang kuasa tetapi sama ada bidang kuasa itu terletak ke atas tangan Mahkamah Syariah. Bidang kuasa Mahkamah Syariah diberi oleh undang-undang negeri tetapi sekiranya undang-undang negeri tidak menganugerah Mahkamah Syariah bidang kuasa yang tersenarai di bawah Senarai Negeri, maka Mahkamah Syariah tidak mempunyai bidang kuasa tersebut di bawah Senarai Negeri. Dan bidang kuasa itu tidak boleh diambil melalui pendekatan tersirat sahaja. 
Perlunya bidang kuasa diberikan secara tersurat dapat juga dilihat dalam kes Latifah Mat Zin lwn Rosmawati Sharibun \& Satu Lagi ${ }^{23}$ di mana Mahkamah Persekutuan berpendapat bahawa Mahkamah Syariah telah terkhilaf dalam kes Jumaaton dan Satu Lagi v Raja Hizaruddin, ${ }^{24}$ bahawa ia isu yang dibawa kepadanya melibatkan probet dan pentadbiran. Walaupun Mahkamah Syariah betul mengatakan probet dan pentadbiran adalah di luar bidang kuasanya yang terletak ke atas Mahkamah Sivil persoalan yang dibawa ke Mahkamah Syariah oleh pemohon ketiga ialah waris-waris berhak kepada bahagian mereka masingmasing menurut faraid merupakan satu persoalan undang-undang Islam yang jelas terletak di bawah bidang kuasa Mahkamah Syariah. Mahkamah Persekutuan menambah lagi bahawa adalah tidak betul bagi Mahkamah Syariah mengambil pendekatan bahawa ia tidak mempunyai bidang kuasa disebabkan probet dan pentadbiran termasuk dalam bidang kuasa Mahkamah Sivil kerana persoalan faraid jelas di bawah bidang kuasa Mahkamah Syariah. ${ }^{25}$

Dalam kes Abdul Kahar Ahmad lwn Kerajaan Negeri Selangor Darul Ehsan; Kerajaan Malaysia \& Yang Lain-lain (Pencelah-pencelah) ${ }^{26}$ diputuskan bahawa sebelum bidang kuasa Mahkamah Sivil boleh disingkirkan, ia hendaklah terlebih dahulu hendaklah ditunjukkan bahawa Mahkamah Syariah mempunyai bidang kuasa terhadap perkara yang dipertikaikan iaitu Enakmen Kesalahan Jenayah Syariah Selangor 1995. Walaupun begitu, hanya Mahkamah Sivil yang mempunyai bidang kuasa untuk memutuskan persoalan sama ada peruntukan yang dicabar berada di bawah kuasa Dewan Undangan Negeri (DUN) atau tidak dan sama ada ianya sah ataupun tidak. Mahkamah Syariah tidak mempunyai bidang kuasa berbuat demikian.

Ini juga disahkan dalam kes Sulaiman Takrib lwn Kerajaan Negeri Terengganu; Kerajaan Malaysia (Pencelah) \& Kes-kes Lain. ${ }^{27}$ Perayu memohon agar seksyen 10 \& 14 Enakmen Kesalahan Jenayah Syariah (Takzir) Terengganu 2001 dan sekyen 51 Enakmen Pentadbiran Hal Ehwal Agama Islam Terengganu 2001 diisytiharkan batal dan tidak sah atas alasan tidak berperlembagaan. Mahkamah Persekutuan memutuskan bahawa peruntukan tersebut diberi kepada bidang kuasa negeri dan Mahkamah Syariah mempunyai bidang kuasa. Justeru itu, kesalahan itu boleh dibicara di Mahkamah Syariah.

Rosli Dahlan \& Fawza Sabila Faudzi berpandangan bahawa, Mahkamah Sivil mempunyai bidang kuasa untuk menentukan apakah perkara ditimbulkan dalam mahkamah itu terletak di bawah bidang kuasa Mahkamah Sivil atau Mahkamah Syariah, hanya Mahkamah Sivil yang mempunyai kuasa menentukannya meskipun ia melibatkan undang-undang Islam. Persoalan pokoknya ialah, apakah bidang kuasa itu disebut dan dianugerahkan dalam enakmen negeri. Sekiranya isu undangundang Islam itu diperuntukkan dalam sesuatu enakmen negeri, maka Mahkamah Sivil mempunyai bidang kuasa membicarakan kes tersebut. ${ }^{28}$ 


\section{Pendekatan kedua: bidang kuasa dimiliki secara tersirat berdasarkan peruntukan perlembagaan}

Pendekatan ini tidak mengkehendaki Mahkamah Syariah diberi bidang kuasa secara jelas atau nyata. Ia memadai walaupun Negeri tidak memperuntukkan peruntukan secara jelas/tersurat dalam perkara tersebut. Apa yang perlu hanya dengan peruntukan secara tersirat. Sebab utama pendekatan ini diambil ialah perkataan 'bidang kuasa' dalam Perkara 121 (1A) Perlembagaan Persekutuan "merujuk kepada bidang kuasa yang lebih luas seperti mana yang diperuntukkan dalam Jadual Kesembilan, Senarai II - Senarai Negeri, Butiran I. Di bawah kategori ini, bidang kuasa tersebut dianugerahkan kepada Mahkamah Syariah meskipun tidak dinyatakan secara tersurat". ${ }^{29}$

Pendekatan ini dapat juga dilihat dalam kes Dalip Kaur lwn Pegawai Polis Daerah Bukit Mertajam \& Anor. ${ }^{30}$ Mahkamah Agung menolak rayuan ibu si mati bahawa anaknya seorang bukan Islam semasa meninggal dunia. Perayu mendakwa bahawa anaknya semasa hayat setelah memeluk agam Islam, telah keluar Islam dengan kembali kepada agama Singh. Mahkamah Agung mengarahkan agar kes ini diserah kembali ke Mahkamah Tinggi kerana beberapa persoalan undang-undang Islam ditimbulkan. Penentuan sama ada seseorang itu telah keluar Islam (murtad) hendaklah ditentukan oleh Mahkamah Syariah. Oleh kerana tiada penentuan telah dibuat bahawa simati bukan Islam semasa kematiannya, maka dianggap seorang Islam. Mahkamah Agung memutuskan bahawa hanya Mahkamah Syariah yang mempunyai bidang kuasa menentukan sama ada seseorang itu masih lagi seorang Islam atau tidak.

Pendekatan yang sama juga diambil dalam kes Md Hakim Lee lwn MAIWP ${ }^{31}$ yang merujuk kepada kes Dalip Kaur lwn Pegawai Polis Daerah Bukit Mertajam \& Yang Lain ${ }^{32}$ di mana perayu yang memeluk agama Islam dan kemudiannya membuat pengisytiharan deed poll dan deklarasi undang-undang bahawa beliau bukan lagi seorang Islam mengikut peruntukan Perkara 11 (1) Perlembagaan Persekutuan yang menjamin kebebasan beragama. Persoalan timbul sama ada Mahkamah Sivil mempunyai bidang kuasa mendengar kes murtad. Diputuskan bahawa Mahakmah Sivil tidak mempunyai bidang kuasa mengenai murtad dan hanya Mahkamah Syariah yang mempunyai bidang kuasa ini walaupun tiada peruntukan jelas dalam Enakmen Negeri.

Dalam kes Soon Singh lwn PERKIM,,$^{33}$ Mahkamah Persekutuan memutuskan bahawa Mahkamah Sivil tidak mempunyai bidang kuasa mendengar permohonan deklarasi murtad. Hanya Mahkamah Syariah mempunyai bidang kuasa bagi menentukan sama ada seseorang itu telah murtad atau tidak. Pihak perayu, semasa di peringkat Mahkamah Tinggi telah memohon satu deklarasi bahawa beliau bukan lagi seorang Islam. Beliau mempertikaan bidang kuasa Mahkamah Syariah mendengar kes ini kerana tiaa peruntukan secara nyata dan jelas dalam 
Enakmen Pentadbiran Agama Islam Kedah 1962. Mahkamah Persekutuan memutuskan bahawa bidang kuasa ini diserahkan kepaa Mahkamah Syariah walaupun tiada peruntukan dalam Enakmen Negeri. Justeru itu, Mahkamah Syariah mempunyai bidang kuasa secara tersirat kerana kalaulah bidang kuasa masuk Islam diletakkan di bawah Mahkamah Syariah, secara tersirat jugalah keluar Islam diletakkan di bawah Mahkamah Syariah.

Tetapi keputusan kes Soon Singh tidak dapat menyelesaikan masalah pertindihan bidang kuasa antara Mahkamah Sivil dan Mahkamah Syariah. Memang betul perkara ini terletak di bawah bidang kuasa Mahkamah Syariah tetapi kalau melibatkan pihak yang bukan Islam, Mahkamah mana mereka akan pergi kalau tidak ke Mahkamah Sivil? Ini adalah kerana, bidang kuasa Mahkamah Syariah hanya diberikan kepada orang yang menganut agama Islam sahaja. ${ }^{34}$ Situasi ini dapat dilihat dalam kes Dalip Kaur lwn Pegawai Polis Daerah Bukit Mertajam \& Anor, ${ }^{35} \mathrm{Ng}$ Wan Chan lwn Majlis Agama IslamWilayah Persekutuan dan satu lagi, ${ }^{36}$ Kaliammal Sinnasamy lwn Pengarah Jabatan Agama Islam Wilayah Persekutuan (JAWI) dan lain-lain ${ }^{37}$ dan A Rayapan $^{38}$ di mana pihakpihak yang terlibat adalah orang bukan Islam.

Dalam kes Tongiah Jumali \& Anor lwn Kerajaan Negeri Johor \& Ors, ${ }^{39}$ Mahkamah memutuskan bahawa Mahkamah Syariah merupakan Mahkamah yang kompeten untuk mengendalikan kes yang melibatkan penentuan keluar Islam walaupun peruntukan sedemikian tidak diperuntukkan secara tersirat dan nyata dalam Enakmen Pentadbiran Undang-undang Islam Johor 1978. Malah, melihat kepada Perkara 121 (1A) Perlembagaan Persekutuan, Mahkamah Sivil tidak mempunyai bidang kuasa untuk mendengar kes permohonan keluar Islam kerana kuasa demikian dan bidang kuasa untuk berbuat demikian terletak ke atas Mahkamah Syariah.

Dalam kes Lina Joy lwn Majlis Agama Islam Wilayah Persekutuan \& Anor ${ }^{40}$ di mana pihak plaintif telah memohon untuk menukar namanya dari Islam kepada bukan Islam dalam kad pengenalannya. Alasan yang dikemukakan oleh plaintif ialah hak kebebasan beragama seperti yang termaktub dalam Perkara 11(1), Perlembagaan Persekutuan. Walau bagaimanapun, Hakim Faiza Tamby menolak permohonan plaintif berdasarkan dua peruntukan lain dalam Perlembagaan Persekutuan. Menurut Hakim, hak kebebasan beragama seperti yang diperuntukkan dalam Perkara 11(1) tidak boleh dibaca berasingan dengan Perkara 3(1) yang memperuntukkan agama Islam sebagai agama Persekutuan. Mengambil kira peruntukan tersebut, kedudukan agama Islam tidak sama dengan kedudukan agama-agama lain kerana agama Islam diletakkan di atas satu tempat yang utama dan dominan dalam Persekutuan. ${ }^{41}$ Oleh kerana plaintif semasa membuat permohonan tersebut masih lagi seorang Islam, dengan mengguna pakai Perkara 160 (2) Perlembagaan Persekutuan, plaintif tidak dibenarkan sama 
sekali meninggalkan agama Islam. Justeru itu, permohonan menukar nama dari nama Islam kepada nama bukan Islam tidak boleh dilakukan selagi mana plaintif seorang Melayu. Hakim yang bijaksana, bagaimanapun berkata bahawa beliau tidak membuat sebarang keputusan berkaitan keputusan pihak plaintif untuk meninggalkan Islam, kerana forum yang layak untuk berbuat demikian adalah Mahkamah Syariah.

Tidak puas hati dengan keputusan Hakim Dato' Faiza Thamby, Azlina Jelani merayu ke Mahkamah Rayuan. Mahkamah Rayuan memutuskan bahawa perayu bebas untuk menganut agama kehendaknya, namun bagi seseorang Islam yang mahu keluar dari agama Islam (murtad), permohonan untuk mendapat perisytiharan hendaklah terlebih dahulu dibuat di Mahkamah Syariah. Ini kerana, Mahkamah Syariah merupakan platform yang sebenar dan Mahkamah Sivil tidak mempunyai bidang kuasa tersebut dengan pindaan Perkara 121 (1A) Perlembagaan Persekutuan pada tahun 1988. Selagi mana Mahkamah Syariah tidak membuat sebarang perisytiharan bahawa seseorang itu bukan lagi seorang Islam, maka orang tersebut hendaklah dianggap sebagai seorang Islam sehingga dia meninggal dunia.

Beliau merayu ke Mahkamah Persekutuan dan menamakan Majlis Agama Islam Wilayah Persekutuan dan JPN sebagai responden-responden. Mahkamah Persekutuan dalam keputusan majoriti 2-1 menolak rayuan terakhir beliau. Mahkamah Persekutuan memutuskan bahawa perkara yang berkaitan dengan keluar Islam (murtad) terletak secara mutlak ke atas Mahkamah Syariah walapun secara tidak langsung (tersirat). Mahkamah Persekutuan menambah bahawa dengan adanya pindaan terhadap Perkara 121 (1A) Perlembagaan Persekutuan, Mahkamah Sivil tidak mempunyai kuasa dalam perkara yang berkaitan murtad. Mahkamah Persekutuan juga berpendapat bahawa keputusan Soon Singh ${ }^{42}$ adalah tepat.

Nampaknya permasalahan pertindihan bidang kuasa belum menampakkan penyelesaian. Ia tidak boleh diselesaikan oleh mahkamah sama ada Mahkamah Sivil ataupun Mahkamah Syariah. Yang boleh menyelesaikan permasalahan ini ialah Parlimen dan Dewan Undangan Negeri. Tun Abdul Hamid Mohamad pernah menyarankan dua pandangan: pertama, apabila terdapat persoalan Syariah dalam kes di Mahkamah Sivil, hakim Mahkamah Sivil hendaklah bersidang dengan hakim Mahkamah Syariah. Kedua, Menyatukan kedua-dua Mahkamah ini. Mungkin satu pendekatan pentadbiran dengan penubuhan Mahkamah Khas seperti mana Mahkamah Muamalat dengan melibatkan kedua-dua hakim Mahkamah Sivil dan Syariah, dapat mengurangkan pertindihan bidang kuasa antara Mahkamah Syariah dan Mahkamah Sivil dalam perkara-perkara yang melibatkan undang-undang Islam dan pihak yang terlibat adalah seorang yang memeluk agama Islam dan seorang lagi tidak. ${ }^{43}$ 


\subsection{Status Lebih Rendah (Inferior Status)}

Terdapat juga Mahkamah Syariah yang merasakan dirinya lebih rendah dari Mahkamh Sivil dengan tidak menggunakan bidang kuasa yang ada bagi mendengar kes-kes yang melibatkan orang Islam. Dalam satu kes Jumaton dan satu lagi lwn Raja Hizaruddin ${ }^{44}$ yang melibatkan tuntutan harta pusaka, Hakim Mahkamah Tinggi Syariah memutuskan bahawa Mahkamah Tinggi Syariah tidak mempunyai bidang kuasa dan kes ini ditolak. Kes ini di rayu ke Mahkamah Rayuan Syariah. Malangnya, sekali lagi, Mahkamah Rayuan Syariah menolak rayuan yang dibuat ke atas tuntutan dalam perkara probet dan surat mentadbir harta orang Islam dengan alasan ia terletak di bawah Senarai 1 Jadual Kesembilan, Perlembagaan Persekutuan yang terpakai juga ke atas orang Islam. Keengganan Mahkamah Syariah untuk menggunakan kuasa yang diberi dikritik hebat oleh Salleh Buang yang menegaskan bahawa pandangan yang mengatakan bahawa Mahkamah Syariah tidak mempunyai bidang kuasa kerana kuasa pembahagian harta pusaka seperti yang diterangkan dalam Seksyen 46 (1) Akta 505 yang disekat oleh rangkai kata probet dan surat mentadbir harta dalam Senarai Persekutuan tidak dapat diterima oleh akal yang waras. ${ }^{45}$

Mahkamah Syariah perlu berani membuat keputusan dan mengambil pendekatan terbuka. Ikutilah contoh kes Datuk Menteri Othman Baginda lwn Dato Omi Syed Alwi ${ }^{46}$, yang menyatakan Perlembagaan Persekutuan merupakan undang-undang bertulis yang tersendiri.

Walau bagaimanapun, dalam kes Latifah Mat Zin lwn Rosmawati bte Sharibun \& Satu Lagi ${ }^{47}$ Mahkamah Syariah dianggap sebagai "mahkamah bawahan" (inferior court) menyamai kedudukan seperti mana yang diberi kepada Mahkamah Sesyen dan Mahkamah Majistret. ${ }^{48}$

\section{Transformasi Mahkamah Syariah}

Dalam meningkatkan mutu dan kualiti perkhidmatan Mahkamah Syariah, beberapa transformasi perlu dibuat. Antaranya:

\subsection{Bidang kuasa}

Seperti yang dibincang sebelum ini, permasalahan bidang kuasa yang terhad yang dianugerahkan kepada Mahkamah Syariah merupakan satu masalah yang masih belum selesai. Walaupun ada cadangan untuk menambah bidang kuasa untuk diberi kepada Mahkamah Syariah, persoalannya, adakah Mahkamah Syariah sudah bersedia untuk memikul tanggung jawab ini? Cuba bandingkan bidang kuasa yang diberikan antara Mahkamah Syariah dan Mahkamah Sivil? Bidang kuasa Mahkamah Tinggi Sivil lebih besar berbanding dengan bidang kuasa Mahkamah Syariah. Tetapi dengan bidang kuasa yang terhad yang diberikan 
kepada Mahkamah Syariah, apakah ia telah digunakan semaksimanya? Banyak kritikan dibuat ke atas penghakiman kes Jumaaton dan Satu Lagi lwn Raja Hizaruddin $^{49}$ di mana Mahkamah Syariah, dalam satu usaha positif, cuba memain peranan seperti Mahkamah Sivil untuk membuat interpretasi perlembagaan yang sebenarnya bukan bidang kuasanya. ${ }^{50}$ Tetapi pada masa yang sama "takut" untuk mengguna bidang kuasa yang diberi kepadanya. Sudah tiba masanya hakim Mahkamah Syariah perlu berani menggunakan kebijaksanaannya untuk menggunakan bidang kuasanya sama ada tersirat atau tersurat.

Dari segi bidang kuasa jenayah, Mahkamah Syariah tertakluk hanya kepada orang Islam dengan had yang dianugerahkan dalam Akta Mahkamah Syariah (Bidang Kuasa Jenayah) 1965 (Pindaan 1984) yang memberi kuasa kepada Mahkamah Syariah menjatuhkan hukuman tiga tahun penjara, denda RM5,000.00 dan sebatan enam kali. ${ }^{51}$ Memandangkan pindaan terakhir berlaku pada tahun 1984, sudah tentulah bidang kuasa ini perlu dinaikkan melalui pindaan di Parlimen. Usaha untuk meminda Akta ini telah dibuat oleh Parti Islam Se-Malaysia dengan memajukan rang undang-undang persendirian di Parlimen bagi meluaskan bidang kuasa Mahkamah Syariah untuk pelaksanaan sebahagian undang-undang jenayah Islam di bawah hudud di Kelantan. ${ }^{52}$

Dalam semakan kehakiman kes AzmiB Mohamad Azam@Roneylwn Pengarah Jabatan Agama Islam Sarawak dll ${ }^{53}$ Mahkamah Tinggi Sivil Kuching memutuskan bahawa pemohon adalah dari keturunan Bidayuh dan beragama Kristian. Ibubapanya memeluk agam Islam sekitar tahun 1983. Hasil dari pemelukan Islam ayahnya pemohon juga mengikut agama baru bapanya sekitar umur lapan tahun dengan diberi nama Azmi Mohamad Azam. Walau bagaimanpun, pemohon dibesarkan dan dididik secara Kristian di kalangan suku Bidayuh dan dibaptiskan pada 4 September 1999. Pemohon tidak mengamalkan ajaran Islam. Pada tarikh 15 Julai 2014, pemohon memohon kepada Jabatan Pendaftaran Negara (JPN) cawangan Limbang memohon penukaran nama pada kad pengenalannya kepada nama bukan Islam tetapi dimaklumkan bahawa pemohon perlu membawa dokumen dari Jabatan Agama Islam Sarawak (JAISr) dan Arahan Mahkamah. Pemohon pergi ke JAISr Limbang dan dimaklumkan JAISr tidak boleh membantu dalam hal ini dan menyuruh pemohon memohon di mahkamah.

Persoalannya ialah apabila peguam pemohon menulis kepada Jabatan Kehakiman Syariah Sarawak (JKSS), jawapan balas oleh Ketua Hakim Syarie dalam surat bertarikh 7 Julai 2015 memaklumkan bahawa JKSS tiada mempunyai bidang kuasa untuk mengeluarkan sijil keluar dari agama Islam.

Memandangkan bahawa JKSS tidak mempunyai bidang kuasa mengeluarkan sijil keluar Islam, peguam pemohon berhujah bahawa JPN tidak mempunyai asas supaya Mahkamah Syariah mengeluarkan sijil tersebut. Respondan 
satu (JAISSr) dan Majlis Agama Islam Sarawak (MAISr) tidak membantah permohonan pemohon untuk keluar Islam. Tetapi JPN tetap dengan pendirian bahawa ia memerlukan satu arahan dari Mahkamah Syariah.

Peguam Persekutuan berhujah bahawa walaupun Ordinan Mahkamah Syariah 2001 tidak menganugerahkan bidang kuasa untuk mendengar kes keluar Islam (murtad), tetapi secara tersiratnya, Mahkamah Syariah mempunyai bidang kuasa berbuat demikian.

Peguam Persekutuan membawa kes-kes seperti Dalip Kaur, Md Hakim Lee, Soon Singh, Shaikh Zulkaffily, Lina Joy dan Hj Raimi bin Abdullah lwn Siti Hasnah Vangaram bt Abdullah. ${ }^{54}$ Namun, Hakim Datuk Yew Jen Kie tidak dapat menerima hujah-hujah tersebut kerana pada hemat beliau, isu yang timbul bukanlah isu bidang kuasa tetapi isu perlembagaan.

Oleh kerana pemohon dibesarkan secara Kristian dalam masyarakat Bidayuh dan mengikut agama ibubapanya sekitar umur 10 tahun, pemohon tidak pernah mengamalkan ajaran Islam malah mengikut ajaran Kristian. Pemohon memohon hak kebebasan beragama seperti yang terkandung dalam Perkara 11 (1) Perlembagaan Persekutuan bahawa beliau adalah seorang yang beragama Kristian.

Angkara keengganan Mahkamah Syariah Sarawak mendengar kes ini akhirnya, ia telah jatuh ke tangan Mahkamah Sivil dengan keputusan bahawa pemohon adalah seorang Kristian; bahawa JPN hendaklah menukar namanya daripada Azmi B Mohamad Azam Shah@Roneey kepada RoneeyAnak Rebit dan memadam perkataan Islam pada kad pengenalan pemohon.

\subsection{Struktur}

Struktur Mahkamah Syariah kini dalam perancangan penambahan menjadi lima hierarki berbanding dengan sekarang yang hanya mempunyai tiga hierarki iaitu Mahkamah Rayuan Syariah-Mahkamah Tinggi Syariah-Mahkamah Rendah Syariah. Dengan lima hierarki: Majlis Rayuan Syariah-Mahkamah Rayuan Syariah-Mahkamah Tinggi-Mahkamah Tengah-Mahkamah Rendah, ia melihat seolah mempunyai persamaan dengan hierarki Mahkamah Sivil. Sebenarnya, struktur ini dicadangkan oleh Seksyen Syariah Jabatan Peguam Negara. Malangnya, cadangan penstrukturan semula oleh JKSM yang hanya menambah satu lagi peringkat rayuan yang dikenali Mahkamah Rayuan Khas Syariah tidak diterima walaupun telah diluluskan oleh kabinet dan Majlis Kebangsaan Hal Ehwal Islam (MKI). Salleh Buang mempersoalkan pendekatan yang diambil oleh kerajaan yang menolak cadangan dari JKSM. ${ }^{55}$ Perbincangan lanjut sedang berlangsung antara JKSM dan Jabatan Peguam Negara melalui satu Jawatankuasa Khas yang dibentuk oleh YB Menteri di Jabatan Perdana Menteri. Ia perlu dibentangkan semula dalam mesyuarat MKI. ${ }^{56}$ Cadangan mewujudkan 
Mahkamah Rayuan Khas Syariah yang dicadangkan oleh Jabatan Peguam Negara di mana Sembilan orang Hakim Mahkamah Rayuan Khas Syariah termasuk seorang Ketua Pendaftar yang akan dibentuk di bawah pekenan Majlis Rajaraja. ${ }^{57}$ Dari pengamatan penulis, tidak semua sultan bersetuju dengan cadangan lima hierarki dan masih terlalu awal untuk melihat ianya menjadi realiti.

\subsection{Penghakiman}

Bandingkan pula corak penghakiman yang ditulis oleh hakim Mahkamah Syariah dengan hakim Mahkamah Tinggi Sivil dan hakim Mahkamah Tinggi Syariah. Perbandingan ini tidak adil kerana kelayakan kemasukan dan skim yang berbeza antara keduanya. Tetapi bukankah sekarang terdapat ramai hakim Mahkamah Tinggi Syariah yang berkelulusan Sarjana Muda Undang-Undang (LLB) dan LLB Syariah/Syariah \& Undang-undang/Syariah, yang mampu merujuk sumber-sumber bahasa Arab dan bahasa Inggeris? Tetapi kalau kita sering membaca penghakiman yang ditulis oleh hakim Mahkamah Syariah, masih ramai hakim menjadikan buku fiqh karangan Dr Wahbah Zuhaili, Fiqh wa Adillatuh sebagai buku rujukan utama. Amat sedikit dan jarang mereka merujuk kepada kitab-kitab klasik muktabar. Tambahan lagi, jarang sekali merujuk kepada buku berbahasa Inggeris walaupun kini terdapat banyak rujukan yang baik dalam bahasa Inggeris. Ada pandangan bahawa kita tidak boleh salahkan hakim Mahkamah Syariah kerana 'entry point' menjadi hakim Mahkamah Syariah adalah sangat berbeza dengan di Mahkamah Sivil. Terdapat peguam kanan sivil yang berpuluh tahun berpengalaman dilantik menjadi hakim Mahkamah Tinggi Sivil. Ini tidak terdapat di Mahkamah Tinggi Syariah. Malah sebelum tahun 1998 dengan penubuhan JKSM, kelebihan perkhidmatan adalah lebih baik lagi di Jabatan Agama Islam dan JAKIM. Akibatnya, ia tidak menarik minat orang untuk mengisi jawatan hakim Mahkamah Syariah. ${ }^{58}$ Tetapi situasi berbeza sekarang dengan tertubuhnya JKSM. Peluang kenaikan pangkat agak mudah dan cepat. Mungkin juga tiada pembantu penyelidikan bagi hakim Makamah Tinggi Syariah dengan kekangan kerja yang menyebabkan ketidaksempatan hakim Mahkamah Tinggi Syariah membuat rujukan yang lebih baik. Meskipun begitu, hakim Mahkamah Rayuan JKSM mempunyai kemudahan pegawai penyelidikan yang dapat membantu mereka dalam mendapat bahan untuk menulis penghakiman.

\subsection{Memperkasa Hakim Wanita}

Buat masa sekarang, hanya segelintir wanita dilantik menjadi hakim di Mahkamah Syariah. Terdapat dua hakim wanita di Mahkamah Rendah Syariah Wilayah Persekutuan (dua jawatan tambahan sedang dalam pertimbangan). Di 
Melaka, dua wanita juga telah dilantik sebagai hakim wanita di Mahkamah Rendah Syariah Melaka. Manakala di Kelantan seorang wanita dilantik sebagai pegawai sulh dan hakim di Mahkamah Rendah Syariah Kelantan.

Nampaknya jumlahnya masih kecil dan perlu penambahan yang ketara. Tambahan pula, tidak terdapat langsung hakim wanita di Mahkamah Tinggi Syariah. Pihak JKSM ada mencadangkan seorang wanita untuk menjadi hakim Mahkamah Rayuan JKSM dengan gred JUSA B (Jawatan Utama Sektor Awam) tetapi masih lagi belum diluluskan oleh kerajaan.

Situasi ini perlu ditangani oleh pihak berkuasa bagi melantik lebih ramai lagi hakim di kalangan wanita. Mahkamah Syariah agak ketinggalan dalam hal ini berbanding dengan Mahkamah Sivil.

\subsection{Emolumen Hakim Syariah}

Emolumen yang dinikmati oleh hakim Mahkamah Syariah teramat rendah berbanding dengan hakim Mahkamah Sivil. Mengambil peringkat hakim Mahkamah Tinggi Sivil dan Mahkamah Tinggi Syariah, kebanyakan hakim Mahkamah Tinggi Syariah memegang gred jawatan LS48 (LS adalah jawatan perkhidmatan perundangan Syariah) dan LS52. Jarang bagi mereka yang memegang gred LS54. Buat masa sekarang terdapat dua hakim Mahkamah Tinggi Syariah Wilayah Persekutuan gred LS54 dan satu di Melaka. ${ }^{59}$ Terdapat satu kes istimewa seorang hakim Mahkamah Tinggi Syariah memegang gred JUSA C (Khas Untuk Penyandang-KUP) sebelum ini yang dipegang semasa berkhidmat di Jabatan Peguam Negara dan dibawa bila berpindah ke Mahkamah Tinggi Syariah Wilayah Persekutuan. Amalan sekarang ialah semua Ketua Hakim Mahkamah Syariah Negeri memegang gred JUSA C.

Bagi gred jawatan hakim di JKSM, Ketua Pengarah/Ketua Hakim JKSM memegang gred TURUS 3 (melebihi Ketua Pengarah JAKIM), manakala hakim Mahkamah Rayuan Syariah JKSM gred JUSA B.

Dalam kertas cadangan Rang Undang-undang Majlis Rayuan Syariah (cadangan lima hieraki Mahkamah Syariah), dicadangkan penubuhan Majlis Rayuan Syariah dengan perlantikan Ketua Hakim dan Hakim Majlis Rayuan Syariah. Gaji yang dicadangkan dalam Rang Undang-undang Saraan Hakim Syarie nampaknya sungguh lumayan yang mungkin setaraf dengan Ketua Hakim Negara. Bagi emolument Ketua Hakim Majlis Rayuan Syariah ialah RM40,600.00 tidak termasuk elaun khas RM12,000.00 dan elaun tahunan yang lain (gaji pokok RM25,000.00).

Sekiranya skim perkhidmatan baru ini dapat dilaksanakan, satu transformasi emolumen akan berlaku dalam perkhidmatan kehakiman Syariah di Malaysia. 


\subsection{Latihan Kehakiman Syariah}

Buat masa sekarang, tiada satu institut latihan khusus bagi kehakiman Syariah. Bagi perkhidmatan kehakiman Sivil, Institut Latihan Kehakiman dan Perundangan (ILKAP) ditubuhkan bagi memberi latihan dan kursus khas dalam perkhidmatan kehakiman dan kepeguaman Sivil. Bagi perkhidmatan kehakiman Syariah, mereka "menumpang" latihan dan kursus di Institute Latihan Islam Malaysia (ILIM) yang ditubuhkan di bawah JAKIM yang bukan dikhususkan kepada kehakiman Syariah sahaja. Satu cadangan penubuhan institut latihan kehakiman seperti ILKAP sedang dalam perancangan yang dikenali sebagai Akademi Kehakiman Syariah Malaysia. Dengan pengwujudan akademi ini, diharap mutu perkhidmatan dan kualiti penghakiman Syariah dapat dipertingkatkan.

\subsection{Pengurangan Kes Tertunggak}

Satu kajian bersama telah dibuat oleh JKSM dengan Majlis Produktiviti Negara bagi melihat keberkesanan pengurusan kes perceraian di Mahkamah Syariah dari tahun 2005-2010 bagi mengenal pasti kelewatan penyelesaian kes perceraian.

Hasil daripada kajian tersebut, satu tindakan drastik dengan membuat post mortem dengan tujuan untuk mencari penyelesaian terbaik bagi mengurangkan kes perceraian tertunggak di Mahkamah Syariah.

Justeru itu, satu ketetapan KPI (Key Performance Indicator) telah dibuat pada tahun 2011 di mana semua kes tertunggak bagi tiga tahun kebelakang (200082010) telah dapat diselasaikan $100 \%$ pada tahun 2011 juga.

KPI ini sebenarnya selaras dengan KPI yang telah dipersetujui oleh semua negeri pada tahun 2008 bahawa semua kes mal (kewangan dan harta) hendaklah diselesaikan dalam tempoh 180 hari (enam bulan) mulai dari kes itu didaftarkan sehingga keputusan dibuat. ${ }^{60}$

\subsection{Memperkasa Pegawai Sulh}

Mendengari dari maklum balas pegawai Syariah di Mahkamah Rendah Syariah, didapati proses Jawatankuasa Pendamai (JP) yang diperuntukkan di bawah seksyen 47 Enakmen/Akta Undang-undang Keluarga Islam nampaknya kurang berkesan. Ini berkemungkinan berkait rapat dengan kelemahan JP itu sendiri.

Tambahan pula, proses Hakam jarang digunakan bagi kes perceraian. Maka bagi mengurangkan tempoh kes perceraian, pemerkasaan Hakam hendaklah dibuat secara komprehensif dan berkesan. Satu jawatan Hakam akan diwujudkan di setiap Mahkamah Syariah Negeri dan Wilayah Persekutuan bagi mengurangkan isu kelewatan kes perceraian dari tempoh satu tahun ke tiga bulan sahaja. ${ }^{61}$ 


\subsection{Pembangunan Infrastruktur}

Pihak JKSM sedang giat membangunkan infrastrutur ibu pejabat Mahkamah Syariah Negeri:

1. Pulau Pinang - RM36 juta (kelulusan tender)

2. Negeri Sembilan - RM27 juta (30\%-40\% pembinaan)

3. Melaka - RM36 juta (50\% pembinaan)

4. Kelantan - RM27 juta (30\%)

5. Sabah - RM36 juta (meratakan tapak)

6. Pahang - dalam proses permohonan peruntukan. ${ }^{62}$

Dengan siapnya insfrastruktur baru ibu pejabat Mahkamah Syariah Negeri, ia dapat memberi satu persekitaran baru tempat kerja yang selari dengan tuntutan semasa, standing atau lebih baik dari infrastruktur Mahkamah Sivil.

\section{Kesimpulan}

Dari perbincangan di atas, dapat disimpulkan bahawa bidang kuasa yang diberikan kepada Mahkamah Syariah adalah sangat terhad seperti yang diperuntukkan dalam Jadual Kesembilan Senarai II Senarai Negeri, Perlembagaan Persekutuan yang hanya meliputi orang Islam, yang terbatas kepada undang-undang personal, pewarisan dan hukuman ke atas mereka yang melanggar ajaran Islam.

Dengan bidang kuasa yang kecil ini, terdapat sesetengah hakim Mahkamah Syariah yang enggan menggunakan bidang kuasa tersebut yang secara relatifnya sangat rendah dengan rakan mereka di Mahkamah Sivil.

\section{Cadangan}

- Bidang kuasa jenayah yang diberikan kepada Mahkamah Syariah di bawah Akta Mahkamah Syariah (Bidang Kuasa Jenayah) 1965 (Pindaan 1984) yang berkuatkuasa 1 Januari 1986 perlu dipinda bagi memberi bidang kuasa jenayah Syariah yang relevan dengan masa. Had sekarang iaitu tiga tahun penjara, RM5,000.00 denda dan sebatan enam kali dianggap rendah bagi Mahkamah Syariah. Sebagai contoh, Parti Islam SeMalaysia (PAS) cuba membawa rang undang-undang persendirian untuk meminda Akta Mahkamah Syariah (Bidang Kuasa Jenayah) 1965 (Pindaan 1984) di Parlimen bagi memeberi laluan pelaksanaan sesetengah peruntukan jenayah hudud di Mahkamah Syariah tetapi sehingga artikel ini ditulis masih belum menjadi kenyataan. Cadangan dan pindaan ini telah sampai 
ke pejabat Peguam Negara dan memerlukan pindaan di Parlimen. Pindaan ini perlu dibuat segera kerana lebih 30 tahun ia tidak dipinda.

- Walaupun Mahkamah Syariah telah tertubuh sebelum negara merdeka (termasuk semasa penjajahan Inggeris), malangnya, pengwujudannya hanya disebut dalam Perkara 121 (1A) dan Jadual Kesembilan, Perlembagaan Persekutuan. Tambahan pula, keputusan Mahkamah Syariah boleh dicabar dan diketepikan oleh Mahkamah Sivil meskipun selepas pindaan kepada Perkara 121 (1A) Perlembagaan Persekutuan. Realitinya, dalam banyak kes, Mahkamah Sivil bukan sahaja mengenepikan keputusan Mahkamah Syariah, tetapi dalam hal-hal tertentu telah campur tangan dalam bidang kuasa Mahkamah Syariah. Selagi amalan pendekatan bidang kuasa eksklusif dan tersurat diterima pakai oleh Mahkamah Sivil, masalah lama seperti pertindihan bidang kuasa akan berlarutan.

- Seharusnya, hakim Mahkamah Syariah hendaklah bersidang bersama hakim Mahkamah Sivil apabila kes mengenai undang-undang Islam dibangkitkan dalam Mahkamah Sivil. Hakim Mahkamah Syariah boleh dipinjamkan ke Mahkamah Sivil apabila ada keperluan. ${ }^{63}$ Ini dapat menyelesaikan kes seperti Dalip Kaur di mana pihak yang memfailkan kes terdiri dari orang bukan Islam. Sedikit pindaan perlu dibuat kepada Perlembagaan Persekutuan dan Akta Mahkamah Kehakiman 1964. ${ }^{64}$

\section{Notes:}

* Mohamed Azam Mohamed Adil, Timbalan Ketua Pegawai Eksekutif, Institut Kajian Tinggi Islam (IAIS) Malaysia/Professor Madya, Akademi Pengajian Islam Kontemporari (ACIS), Universiti Teknologi MARA, Shah Alam, Selangor.

1. Artikel yang dikemaskini berdasarkan kertas kerja yang dibentangkan dalam Seminar on Islamic Law in Practice with Global Perspective, anjuran Jabatan Syariah dan Undang-undang, Akademi Pengajian Islam, Universiti Malaya, 10 Disember 2013.

2. "Pindaan Undang-Undang Syariah: Syor Hukuman Lebih Berat", www.bharian. com.my, 9 November 2013. Tetapi sehingga bulan April 2016, cadangan ini masih belum menjadi kenyataan.

3. Ahmad Ibrahim and Ahilemah Joned, The Malaysian Legal System, $2^{\text {nd }}$. ed. Dewan Bahasa dan Pustaka, 1995, pp.15-6; Abdullah Alwi Haji Hassan, The Administration of Islamic Law in Kelantan, Dewan Bahasa dan Pustaka, 1996, hh.1-3; Hamid Jusoh, The Position of Islamic Law in the Malaysian Constitution With Special Reference to the Conversion Case in Family Law, Dewan Bahasa dan Pustaka, 1991, h. 12-3; Ahmad Hidayat Buang, The Prohibition of Gharar in the Islamic Law of Contracts, $\mathrm{PhD}$ Thesis, SOAS, University of London, 1995, hh. 65-6; Mahmood Zuhdi Ab. Majid, Pengantar Undang-undang Islam 
di Malaysia, Penerbit Universiti Malaya, 1997, hh.52-3.

4. Supra.

5. [1915] 1 FMSLR 204-214

6. [1972] 6 FMSLR 128.

7. Ahmad Ibrahim and Ahilemah Joned, The Malaysian Legal System, supra, h. 72.

8. [1971] 1 MLJ 265.

9. [1939] MLJ 209.

10. Ahmad Ibrahim and Ahilemah Joned, The Malaysian Legal System, supra, hh. 53-57; lihat juga Michael G. Peletz, Islamic Modern - Religious Courts and Cultural Politics in Malaysia, Princeton University Press, New Jersey, 2002, hh. 25-63; Lihat juga Nizam Bashar, The Application of Shariah Law in Malaysia dalam G25 Malaysia, Breaking the Silence - Voices of Moderation - Islam in a Constitutional Democracy, Marshall Cavendish Editions, Singapore, 2016, hh. 20-30.

11. Supra.

12. Supra.

13. Mohamed Azam Mohamed Adil, "Bidang kuasa dan Kedudukan Mahkamah Syariah di Malaysia Pasca Alaf 20: Ke Arah Mana?” Jurnal Syariah, 8:2 [2000] hh. 107-108.

14. Mohamed Azam Mohamed Adil \& Nisar Mohammad Ahmad, "Islamic Law and Human Rights in Malaysia", Islam and Civilisational Renewal, Vol. 5. No. 1, January 2014, hh. 46-48; Mohamed Azam Mohamed Adil, "The Scope of Islamic Law and the Inferior Status of the Shari'a Courts in Malaysia", ISCOL 2006, KUIM; lihat juga Mohamed Azam Mohamed Adil, "Law of Apostasy and Freedom of Religion in Malaysia", Asian Journal of Comparative Law, 2007, Article 6, hh 29-35; Ahmad Hidayat Buang, Mahkamah Syariah di Malaysia - Pencapaian dan Cabaran, Penerbit Universiti Malaya, 2005; Narizan Abdul Rahman, Bidang kuasa Mahkamah dan Konflik Perundangan dalam Ahmad Hidayat Buang, Mahkamah Syariah di Malaysia - Pencapaian dan Cabaran, Penerbit Universiti Malaya, 2005, hh. 47-78.

15. Ahmad Mohamed Ibrahim, The Administration of Islamic Law in Malaysia, IKIM, 2000, hh. 37-59.; Narizan Abdul Rahman, Bidang kuasa Mahkamah dan Konflik Perundangan, supra, hh. 49-51.

16. [1992] 2 MLJ 793; lihat juga [1993] 5 KANUN (1) 78.

17. [1994] 1 MLJ 690; [1999] 1 MLJ 489.

18. [1991] 3 MLJ 487.

19. Supra, 489.

20. [1996] 3 CLJ. Kes ini dipetik untuk tidak bersetuju dalam kes Md Hakim Lee lwn Majlis Agama Islam Wilayah Persekutuan Kuala Lumpur [1998] 1 MLJ 681.

21. Ibid.

22. [1997] 3 MLJ 281

23. [2007] 5 CLJ 253.

24. [1998] 6 MLJ 556.

25. Mohamed Azam Mohamed Adil, "Bidang kuasa dan Kedudukan Mahkamah Syariah di Malaysia Pasca Alaf 20: Ke Arah Mana?, supra, hh. 107-108.

26. [2008] 1 CLJ (SYA) 1

27. [2009] 2 CLJ 54. 
28. Rosli Dahlan \& Fawza Sabila Faudzi, The Position of the Shariah Court in the Malaysia Legal System dalam G25 Malaysia, Breaking the Silence - Voices of Moderation - Islam in a Constitutional Democracy, Marshall Cavendish Editions, Singapore, 2016, hh. 104-115.

29. Pawancheek Marican, "Murtad (Apostasy) and Art 121 (1A) of the Federal Constitution", [1998] 2 MLJ lxxviii.

30. [1992] 1 MLJ 1.

31. [1998] 1 AMR 74; [1998] 1 MLJ 681.

32. [1992] 1 MLJ 1.

33. [1999] 1 MLJ 489; [1999] 2 AMR 1211.

34. Jadual Kesembilan, Senarai II, Senarai Negeri, Perlembagaan Persekutuan.

35. [1992] 1 MLJ 1.

36. [1991] 3 MLJ 487.

37. [2006] 1 CLJ 753; [2011] 2 CLJ 165, CA

38. Lihat Mohamed Azam Mohamed Adil, "Undang-undang atau bidang kuasa?" Utusan Malaysia, 10 Disember 2006,http://ww1.utusan.com.my/utusan/info. asp? $=2006 \& d t=1210 \& p u b=U t u s a n \_$Malaysia\&sec=Rencana\&pg=re_05.htm.

39. [2004] 5 MLJ 40.

40. [2007] 3 AMR 693.

41. Takrifan yang seperti ini dapat juga dilihat dalam kes Meor Atiqulrahman bin Ishak \& Anor lwn Fatimah Bte Sihi \& Anor [2000] 5 MLJ 375.

42. Supra.

43. Sila lihat www.tunabdulhamid.my, "55 Tahun Pelaksanaan Peruntukanperuntukan Mengenai Islam dalam Perlembagaan Persekutuan: Masalah dan Penyelesaian", Syarahan Perundangan Islam, Jabatan Syariah \& Undangundang, Akademi Pengajian Islam, Universiti Malaya, 22 Mei 2013. Lihat juga Mohamed Azam Mohamed Adil \& Ahmad Badri Abdullah, Penukaran Agama Kanak-kanak: Isu dan Cadangan, Kertas Polisi IAIS Malaysia, 2016; Mohamed Azam Mohamed Adi, Penentuan Agama dan Hak Penjagaan Kanak-kanak Menurut Undang-undang Islam, JAKIM, 2014

44. [1998] 6 MLJ 556.

45. Lihat perbincangan ini dalam Mohamed Azam Mohamed Adil, "Bidang kuasa dan Kedudukan Mahkamah Syariah di Malaysia Pasca Alaf 20: Ke Arah Mana?, supra, hh. 107-108.

46. [1981] 1 MLJ 29.

47. [2007] 5 MLJ 101 di 114G.

48. Koh Kek Hoe \& Fawza Sabila Faudzi, Trends in Judicial Review of Shairah Matters dalam G25 Malaysia, Breaking the Silence - Voices of Moderation Islam in a Constitutional Democracy, Marshall Cavendish Editions, Singapore, 2016, h. 120.

49. [1998] 6 MLJ 556; Shad Saleem Faruqi, Shariah Laws, Civil Laws and the Federal Constitution dalam G25, Breaking The Silence - Voices of Moderation -Islam in a Constitutional Democracy, 2016, hh. 55-75.

50. Ini dapat dilihat kes Latifah Mat Zin lwn Rosmawati Sharibun \& Yang Lain [2007] 5 CLJ 253.

51. Jadual Kesembilan Senarai II, Senarai Negeri Perlembagaan Persekutuan; lihat juga Shad Saleem Faruqi, Shariah Laws, Civil Laws amd the Fedral Constitution, 
supra, hh. 58-75.

52. "PAS Tetap Akan Bentang Usul Pinda Akta Mahkamah Syariah", 30 Mac 2015, http://www.mstar.com.my/berita/berita-semasa/2015/03/30/pas-tetap-bentangusul/

53. KCH-25-7/12-2014 - keputusan 24 Mac 2016.

54. [2014] 3 MLJ 757.

55. Salleh Buang, "Penstrukturan Semula Mahkamah Syariah", Utusan Malaysia, 16 Disember 2014, http://www.utusan.com.my/rencana/penstrukturan-semulamahkamah-syariah-1.36909.

56. Tan Sri Ibrahim Lembut, "Pelan Tindakan Transformasi Mahkamah Syariah: Peranan dan Cabarab Jabatan Kehakiman Syariah Malaysia (JKSM)" dalam Laporan Kajian Pemacuan Transformasi Sistem Perundangan Islam di Malaysia (2010-2012), IKIM dll, 2013, h. 100.

57. Supra.

58. Wawancara dengan Dr Naim Mokhtar, Timbalan Pengarah Bahagian Sokongan Keluarga (ketika itu), JKSM, 29 November 2013.

59. Wawancara dengan Dr. Naim Mokhtar, supra.

60. Tan Sri Ibrahim Lembut, supra, h. 101.

61. Supra, hh. 102-103.

62. Supra, h. 105.

63. Tun Abdul Hamid Mohamad, supra, hh. 8-9.

64. Supra. 